\title{
RETRACTION Safety and efficacy of sildenafil citrate in the treatment of Parkinson-emergent erectile dysfunction: a double-blind, Placebo controlled, randomized study
}

\author{
MR Safarinejad ${ }^{1}$, A Taghva $^{2}$, B Shekarchi ${ }^{3}$ and Sh Safarinejad ${ }^{1}$ \\ ${ }^{1}$ Private Practice of Urology and Andrology, Tehran, Iran; ${ }^{2}$ Department of Psychiatry, Aja University of Medical Sciences, \\ Tehran, Iran and ${ }^{3}$ Department of Radiology, Aja University of Medical Sciences, Tehran, Iran \\ International Journal of Impotence Research (2011) 23, 94; doi:10.1038/ijir.2011.11
}

Retraction to: International Journal of Impotence Research (2010); 22: 325-335; advance online publication, 23 September 2010; doi:10.1038/ ijir.2010.23
This article has been retracted by the publisher. 